\title{
The Aesthetics of a Three-Way Pattern: The Musical Concept of Talempong Renjeang and The Social System of The People of Luhak Nan Tigo Minangkabau
}

\author{
Andar Indra Sastra \\ Institut Seni Indonesia (ISI) Padangpanjang, Sumatra Barat \\ Email: andarstsipp@gmail.com
}

\begin{abstract}
The goal of this article is to discuss the aesthetics of the three-way pattern in the musical concept of talempong renjeang (tenteng) and the social system of the people of Luhak Nan Tigo Minangkabau. The musical concept of talempong renjeang is formed by 3 (three) pairs of talempong: talempong Jantan, talempong Paningkah, and talempong Pangawinan. As the 'leader', the talempong Jantan maintains the consistency and integrity of the theme and danyuik (tempo) of the playing, the talempong Paningkah follows the lead of the talempong Jantan using different playing motifs, and the talempong Pangawinan has the role and authority to make the guguah (melody) of the talempong complete - creating a three-way aesthetical pattern. The social system of the people of LuhakNan Tigo was created by three legendary figures, namely Dt. Katumangguangan, Dt. Parpatiah Nan Sabatang, and Dt. Nan Sakelap Dunia (RajoBabandiang). From these three figures, the concept of tali tigo sapilin, tungku nan tigo sajarangan was born (a philosophy of harmony). The method used for the research is based on qualitative data which was collected through observation, interviews, and documentation. The data analysis focuses the talempong renjeang as a musical and the social system of the Minangkabau community which began with two legendary Minangkabau figures. The results of the study show that talempong as a musical system corresponds to, or synchronizes with, the social concept of the people of Luhak Nan Tigo Minangkabau.
\end{abstract}

Keywords: aesthetics of a three-way pattern, Luhak Nan Tigo, Minangkabau, musical concept, social system, talempong renjeang

\section{INTRODUCTION}

The word aesthetics comes from the Greek word aisthetika which means things that are absorbed by the senses. For this reason, aesthetics is often understood to mean a sense of perception and the variety of feelings it arouses (Ali, 2011: 1-2, Pramono, 2009: 1). However, aesthetics is no longer solely a philosophical issue since it is also concerned with the scientific or scholarly discussion related to a work of art (Dharsono, 2007: 3). Aesthetics means studying art as an object of beauty - which brings pleasure - by observing it with the five senses in all its complexity - in this case with reference to talempong renjeang (talempong which is portable or carried by the players - ditenteng). Talempong renjeang is a kind of rhythmic percussion music found in Luhak Nan Tigo Minangkabau which consists of 6 (six) gong chimes or momong (Bali: pencon). In this article, the different pitch levels of the six momong talempong are referred to as $\mathrm{T} 1, \mathrm{~T} 2, \mathrm{~T} 3, \mathrm{~T} 4, \mathrm{~T} 5$, and T6. The six momong are the basis for the formation 
of the three talempong pairs - the three-way pattern - known as talempong Jantan, talempong Paningkah, and Talempong Pangawinan.

Sedyawati states that Luhak Nan Tigo is recognized as the homeland in the Minangkabau tradition, and is made up of the areas Luhak Tanah Data, Luhak Agam, and Luhak 50 Koto. In the Minangkabau tradition, this original land or homeland is also known as "darek" - or land, as opposed to "pasisie" - or coast, which literally means a place beside the sea (Edi Sedyawati, 2007: 337). Sjafri Sairin states that areas outside the darek are known as rantau, or settlement areas that developed subsequently for the Minangkabau people. These areas are located primarily to the west and east of Luhak Nan Tigo (Sairin, 1995: 87). In terms of the cultural and geographical aspects of Minangkabau, MD. Mansoer et al writes that geographically Minangkabau is an area or region which is made up of geographical, politicaleconomic, and cultural-historical units, commonly referred to as Darek, Pesisir, and Rantau. In a cultural sense, the word Minangkabau can be used to describe the Minangkabau ethnic community and Minangkabau culture (Mansoer, 1970: 2). One part of the Minangkabau culture is its art, which includes the art of talempong renjeang.

Talempong renjeang is a genre of Minangkabau art performed by three musicians, each of whom plays two talempong which are held or carried (direnjeang) in the left hand and struck (diguguah) by a special mallet (pengguguah) held in the right hand, creating a melody that is unique to the art of talempong renjeang Minangkabau. Boestanoel Arifin Adam states that the term talempong in Minangkabau refers to a type of instrument known as an idiophone, which can be found in various shapes and sizes, and may be made from various different materials, and which is played by being struck. In the most general sense of the word, the talempong is a musical instrument shaped like a small gong which is made from a metal alloy and struck with a mallet (Adam, 1986/1987: 9-10). Talempong renjeang is one of the instruments which falls into the common description given by Boestanoel.

In musical terms, talempong rejeang consists of three pairs of talempong, each pair being known by various different names. This article will use the terms most common to the community to which the music belongs, namely talempong Jantan - T6 and T1, talempong Paningkah - T5 and T3, and talempong Pangawinan - T4 and T2. The three pairs of talempong, T6 and T1, T5 and $\mathrm{T} 3$, and $\mathrm{T} 4$ and $\mathrm{T} 2$, reflect the musical structure of the performance. The talempong pair T6 and T1 always begins the performance and acts as the leader throughout. As the leader, the talempong pair T6 and T1 plays the opening melody and guides the imagination of the other players who are playing the talempong pair $\mathrm{T} 5$ and $\mathrm{T} 3$ and $\mathrm{T} 4$ and T2 so that they can identify the type of guguah (melody) that will be performed. Hajizar states that as the leader, the musician playing the talempong pair T6 and T1 not only has the role of determining the type of guguah to be played, but is also responsible for controlling the danyuik (tempo) of the performance, although the dynamics, or kareh-lunak, are controlled by the talempong Pangawinan (Hajizar, interview, 24-112013). This means that musically speaking, each of the talempong pairs has its own primary role, function, and authority - existing within a threeway conception.

On the other hand, in the social system of the Minangkabau community, there is a concept known as talitigosapilin, tungku nan tigo sajarangan (a philosophy of harmony which literally means "a rope made of three strands, a stove supported by three stones"). The appearance of this concept in the social lives of the Minangkabau community is related to the ideological conflict between two legendary figures, namely Dt. Katumangguangan and Dt. Parpatiah Nan Sabatang. The conflict between these two figures gave rise to two systems of power, known asLareh Koto Piliang and Lareh Bodi Caniago. These two systems influenced the social system of the Minangkabau community. The conflict between the two figures did not come to an end, and eventually a third figure also emerged, namely Rajo Babandiang, who is better known as Dt. Nan Sakelap Dunia. The three-way pattern that was formed and caused by these differences in ideology has similarities with the three-way pattern that exists in the musical concept of talempong renjeang. In connection with this, the goals of this research study are: first, to discover how the aesthetics of the three-way pattern are 
formed as a musical system in the talempong renjeang; second, to observe how the three-way pattern - of harmony - exists in the social system of the Minangkabau community. The method used in this research is based on qualitative data which was obtained through observation, interviews, and documentation. The literature used for this study can be grouped into four categories: first, literature related to the field of aesthetics, using the concepts and ideas of Matius Ali, Darsono (SoniKartika), YakobSumardjo, Kartini Pramono, and Andar Indra Sastra. Second, literature related to historical, cultural, political, and anthropological perspectives, including works by Christine Dobbin, Tsuyoshi Kato, T.O. Ihromi, Koentjaraninggrat, Ali Akbar Navis, Mochtar Naim, Sjafri Sairin, Edi Sedyawati, Taufik Abdullah, and Zaiyardam Zubir. From these writers, conceptual ideas were found that could be used for describing the concept of harmony in the Minangkabau community. Third, the work by Fritjof Capra which is used as a reference for the philosophical aspect of the study, and fourth, the sociological perspective, which refers to the work by George Ritzer\& Douglas J. Goodman. All of this literature is mutually complementary and is used according to the needs of the study.

\section{FINDINGS AND DISCUSSIONS}

\section{The Musical Aesthetic of the Three-Way Pattern inTalempong Renjeang}

The musical aesthetic of the three-way pattern in talempong renjeang begins with a two-way pattern, namely jantan jo batino (male and female), or ujuang jo pangka (tip and base)binary opposition. Andar Indra Sastra states that aesthetically, the concept of jantan-batino - the two-way pattern - refers to a pair of talempong and is the origin of the formation of the talempong music system which consists of 6 (six) different pitches, known as the basic sounds or bunyi pokok (Sastra, 2016: 13). Philosophically, the creation of 6 (six) different pitches refers to the concept of banjanjang naiak-batanggo turun (going up in level-going down by step). Going up in level refers to the sound of the talempong batino, with the concept ditingkek janjang duo dari bawah (up two levels from the bottom). This means that the sound of the talempong batino with the addition of two different pitch levels becomes T1, T2, and T3. Batanggo turun refers to the talempong jantan, with the concept ditapiak tango duo dari ateh (down two steps from the top). This means that from the talempong jantan, two lower pitch levels are added. When these two concepts are put together, they create the music system of talempong in Luhak Nan Tigo Minangkabau, a system that consists of 6 (six) different sound levels or pitches, which are known culturally as anam salabuhan (a set of six). Visually, the music system of the talempong can be illustrated as in the following diagram.

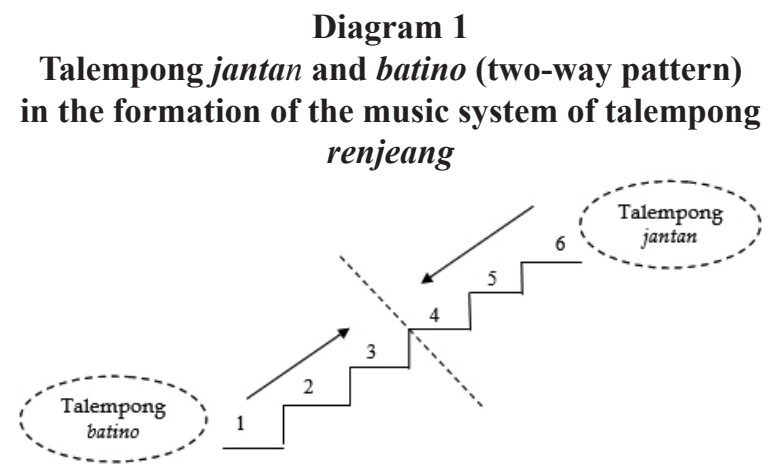

The diagram above explains how the formation of the musical system of talempong begins with the concept of jantan-batino - binary opposition. Ahimsa states that there are two understandings of binary opposition: first, binary opposition which is mutually exclusive in nature, for example the categories of married and unmarried. The second understanding is binary opposition which is not mutually exclusive in nature, and this occurs in various cultures and natural phenomena, such as day-night, stars-moon, water-fire, and so on (Ahimsa, 2001: 70). The concept of jantanjo batino (male and female) or ujuang jo pangka (tip and base) - T6 and T1 - is a form of binary opposition that is not mutually exclusive. Capra views these differences as different forms - poles - of the same reality of the extreme parts of a single unit or whole - polar and bipolar (Capra, 2005: 142). According to Bakker, in a relationship of bipolarity, although there may be harmony or disharmony between the two poles, they always remain an equal distance 
from the central point. They are both a mutually reinforcing unit and bipolarity (Bakker, 1995: 55). This bipolarity in the form of jantan-batino is the philosophical basis for the formation of the music system of talempong - T1, T2, T3, T4, T5, and T6; anam salabuhan. The talempong music system is the basis for the formation of the musical system with a three-way pattern - in talempong renjeang, which consists of talempong Jantan, Paningkah and Pangawinan.

The formation of a three-way pattern as a musical system is based on the concepts of lipek $d u o$ and dipatukakan (doubled and interchanged), as described by Andar Indra Sastra (Dissertation: 2015: 27; Humaniora, 2015: 44; International Symposium: 2016: 17), as follows:

Lipek duo and dipatukakan are methods used for arranging the pitches in the talempong music system. In the talempong music system, the pitches are arranged in order, from the talempong with the lowest pitch to the talempong with the highest pitch, or vice versa $-\mathrm{T} 6, \mathrm{~T} 5, \mathrm{~T} 4$, T3, T2, T1, or T1, T2, T3, T4, T5 and T6. The last three talempong are then moved to the bottom - referred to as dilipek duo. In this way, the talempong begin to appear in pairs, and subsequently, the talempong in the final position - on the second line, is exchanged with the talempong in the middle. Ultimately, this forms the three musical concepts of talempong pairs (Andar: 2015: 27) - see the diagram below.

\section{Diagram 2}

Methods of lipek duo and dipatukakan (doubled and interchanged) Created by Andar, 2015
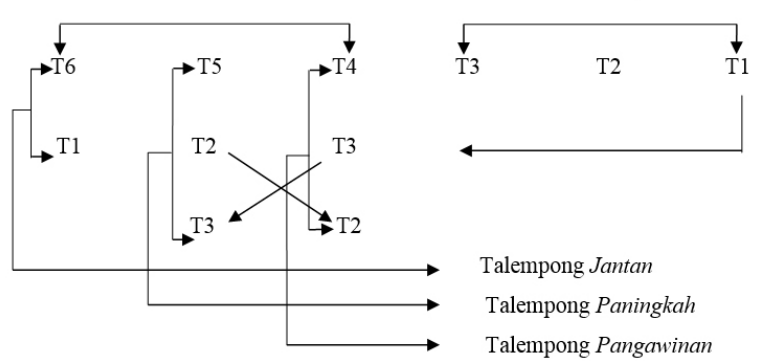

Talempong Jantan

Talempong Paningkah

Talempong Pangawinan

The diagram above illustrates the process by which the musical system of talempong renjeang was formed based on the concepts of lipek duo and dipatukakan. These concepts form a pattern of three pairs of talempong, known as talempong Jantan, talempong Paningkah, and Talempong Pangawinan. In performance, the aesthetics of the three-way pattern appears as in the photograph and diagram below.

Photo 1

Performance of talempong renjeang in the Minangkabau community (Photo: DocumentationAndar 2014)

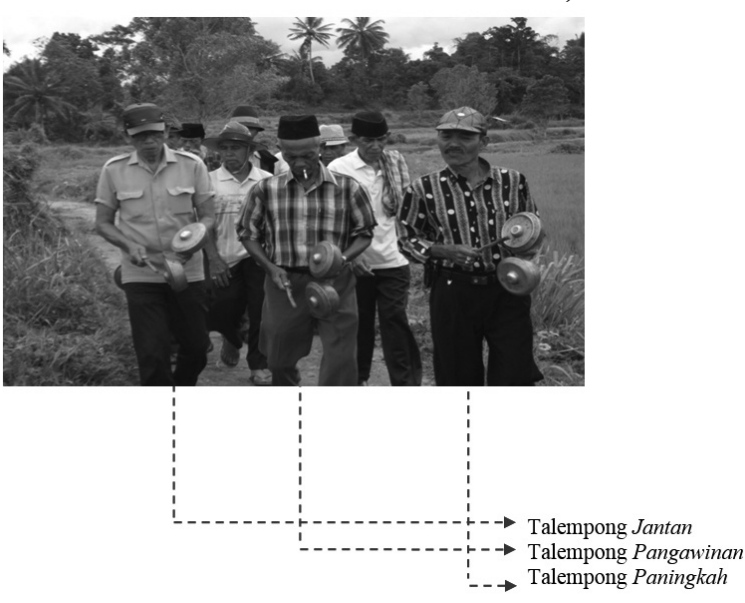

The photograph above shows how musically the performance of the talempong renjeang consists of the pairs of talempong Jantan, talempong Paningkah, and talempong Pangawinan - a threeway aesthetical pattern. Musically, the differences in the rhythmical motifs of the patterns created by each of the talempong pairs forms a melody - a "middle world" - which aesthetically the Minangkabau community refer to as batalun (see diagram 3 below).

\section{Diagram 3}

Aesthetics of the three-way pattern in talempong renjeang

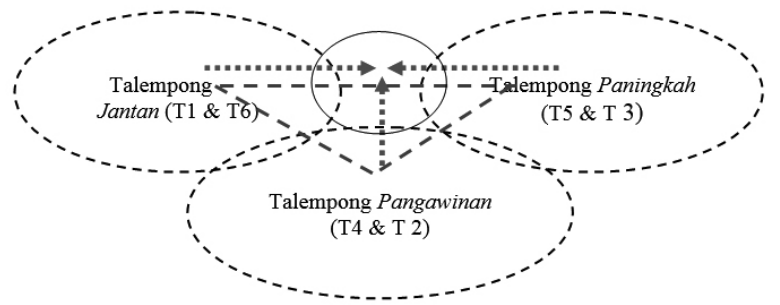

Note:

:...; = Pair of talempong 


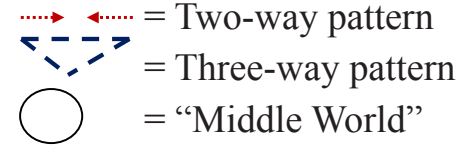

The three-way pattern illustrated above is strongly rooted in the Minangkabau culture, as seen in the expressions tali tigo sapilin and tungku nan tigo sajarangan. The three elements form a unit - a harmony - and musically form a medium for creating batalun - a high aesthetical quality. Jacob Sumardjo states that the aesthetics of the three-way pattern focuses on the formation of paradoxical symbols in the form of a "middle world" which creates harmony among all things that are dualistic-antagonistic (Sumardjo, 2010: 261). The three-way pattern tends to be horizontal, displaying equality in different powers.

\section{Three-Way Pattern: Talempong Renjeang in Traditional Historiographical Dimensions}

From the point of view of its symbolic meaning, the various dimensions of the concept of talitigo sapilin-tugku tigo sajarangan show that there is a synchronization between the three-way pattern in the musical concept of talempong renjeang and the three-way pattern in the general concept of Minangkabau culture. From its traditional historiographical dimension, or its local history, the formation of the three-way pattern in talempong renjeang has a philosophical meaning that is quite similar to the three-way pattern in the concept of Minangkabau culture. Culturally, the emergence of the concept Luhak Nan Tigo was closely related to two legendary figures from Minangkabau, who later became better known as Dt. Parpatiah Nan Sabatang and Dt. Katumangguangan. According to legend, these two figures were involved in ideological conflict, especially after the end of the reign of Adytiawarman - 1347-1375 - in Minangkabau. According to Christine Dobbin, King Adytiawarman had a mixture of Javanese and Sumatran blood and had been raised in the court of Majapahit. He arrived in Sumatra in the 1340s to take control of the area of Dharmasraya, in the upstream region of the Batang Hari River, a region that was famous for its export of gold and had been presented as a tribute to the Majapahit ancestors in Java in the 1270s (Dobbin, 1992: 71). From this point, Minangkabau history enters into an oral tradition - a traditional historiography, which the people call tambo.

This tradition consistently refers to two legal officers, Dt. Parpatiah Nan Sabatang and Dt. Katumanggungan, who according to legend fought over the implementation of the government system after the death of Adityawarman. This gave rise to two political-legal systems: Kalarasan Koto Piliang created by Dt. Katumangguangan and Kalarasan Bodi Caniago, founded by Dt. Parpatiah. According to Dobbin, Koto Piliang was the starting point for the creation of the group identity and descendants of those who belonged to the main tribes of Koto and Piliang. Bodi Canigo was the point of reference for the formation of groups or tribes under the government system of Bodi Caniago. The two main tribes which belonged to this system were the Bodi tribe and the Caniago tribe (Dobbin, 1992: 72). These two sources of law began the political and legal conflict between the followers of Parpatiah and Katumangguangan, and every district was subsequently inclined to follow one of the two traditions.

Politics and the law were associated with the government systems that are referred to as kalarasan and originated from these two legendary figures. Christine Dobbin states that each of the two figures created his own government system and had followers from various districts in Minangkabau. The system created by Dt. Parpatiah Nan Sabatang was known for its concept of mambusek dari Bumi (bursting from the Earth), which was more democratic in nature. In this system, government decisions were made by holding discussion forums and then reaching a consensus. The government system of Dt. Parpatiah Nan Sabatang is also often referred to as the Lareh Bodi Caniago community (Dobbin, 1992: 72). Dt. Katumangguangan created the Koto Piliang system, which was more autocratic in nature but still contained an element of discussion. Decisions were only discussed on the level of the highest leaders and the people had to accept the results of the decisions that were made by the leaders. The style of the Koto Piliang government system is described by the term manitiak dari ateh (dripping down from above), meaning that instructions were given from above. In other words, the government system of 
Dt. Katumangguangan was oriented towards the imperial or kingdom system. This was what led to the two systems, which were based on different ideologies, to become involved in political and legal conflict in Minangkabau.

The conflict between these two figures eventually caused both systems to be implemented in every district. According to Christine Dobbin, all the districts implemented different legal traditions - known as laras. Limo Kaum was the centre of all the districts according to the system of Bodi Caniago, while Sungai Tarab was the center of the opposing tradition - lareh Koto Piliang (Dobbin, 1992: 72). Both of these districts are in Luhak Tanah Data. Mochtar Naimstates that these two figures created phratry dualism which to this day continues to influence various aspects of Minangkabau life and culture. To the outside and in totality, it was regarded as one, but to the inside it created a social and cultural system that was dialectical, dichotomous, and bipolar (Naim, 1983: 56). This bipolarity in the ideological conflict caused a third figure to emerge - Rajo Babandiang, who took the initiative to integrate the two conflicting systems in a third system known as Lareh Nan Bunta or Lareh Nan Panjang. Over the course of time, and with the migration or movement of the people, in some districts there has of course been an integration of the two traditions mentioned above. Christine Dobbin believes that in general, districts that are purely Koto Piliang are more prominent in Luhak Tanah Data, while those that are purely Bodi Caniago are mainly in Luhak Agam. Meanwhile, in Luhak 50 Koto, there is a combination of the two (Dobbin, 1992: 73).

The Lareh Nan Panjang system developed by Rajo Babandiang was a combination of kalarasan Koto Piliang in the structure of its traditional authorities and kalarasan Bodi Caniago in the implementation of its government system. The government model that combines these two systems is referred to with the expression Adaik Koto Piliang, Langgam Bodi Caniago. A.A. Navis states that in Luhak Agam, the districts which implement the two systems are known as lareh nan bunta, which means circular districts. In Tanah Datarthe term lareh nan panjang is used, which means long districts. The meaning of the words bunta and panjang can be understood as an expression which contains the same meaning (Navis, 1986: 56). Lareh Nan Bunta and Lareh Nan Panjang in the system of leadership in the Minangkabau community is a synthesis in creating a dialectical balance between kalarasan Bodi Caniago and kalarasan Koto Piliang. There is a traditional saying which describes Lareh Nan Bunta or Lareh Nan Panjangas follows:

\section{Pisangsikalek-kalekutan (Sikalek-kalek banana of the forest) \\ Pisang tambatu nan bagatah (Banana with seeds and sticky sap) \\ Bodicaniago inyo bukan ( $\mathrm{He}$ is not \\ Bodicaniago) \\ Koto Piliang inyo antah (Nor is he Koto Piliang)}

This traditional saying illustrates how their system does not take the side of either kalarasan bodi caniago or kalarasan kotopiliang, but instead it combines the two. In the expression, which is in the form of verse, or pantun, it states that "It is not Bodi Caniago, nor is it Koto Piliang". Both lareh nan bunta and lareh nan panjang indicate the existence of a consensus which symbolizes the process of synthesis in an endeavor to find harmony and balance (see diagram below).

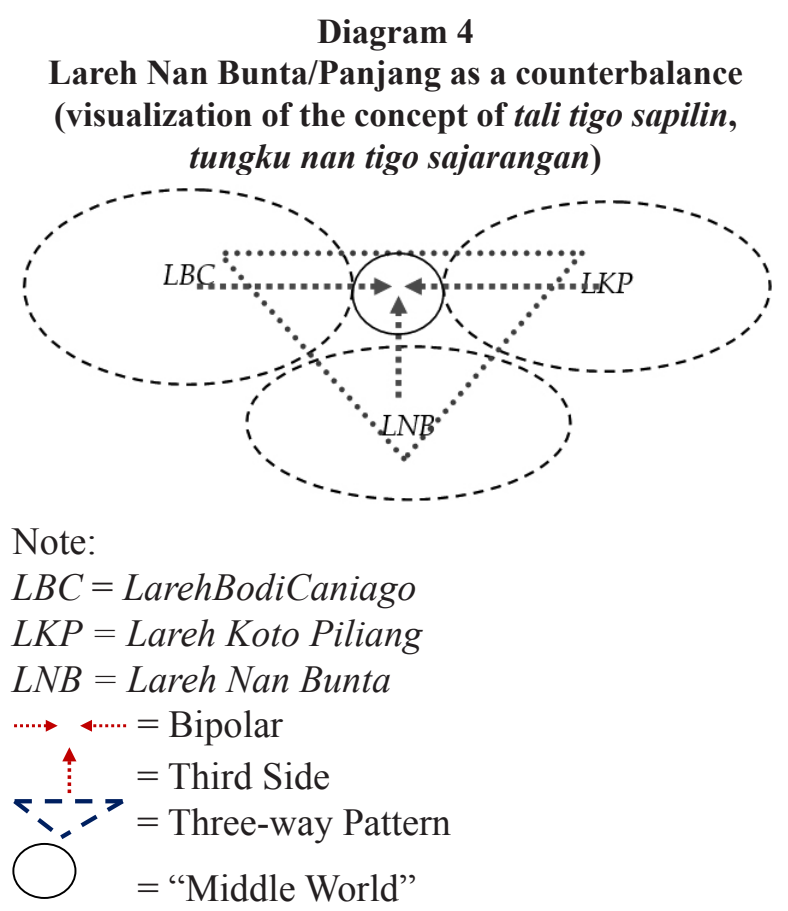


The diagram above shows that the dialogical or dialectical process - bipolarity - that occurred between Lareh Bodi Caniago and Lareh Koto Piliang gave rise to Lareh Nan Bunta/Panjang which symbolizes the process of synthesis to create balance and harmony. Yakob Sumarjo states that the wisdom of the Minang people lies in their harmony; nothing that is dualistic can be resolved with one side winning and the other side losing but both must continue to exist as themselves [exist within two conceptions]. Hence, harmony is a paradox in peace (Sumardjo, 2010:
268). However, one thing that escapes Sumarjo's observation is that this paradox gave rise to a third side, namelyLareh Nan Bunta/Panjang - creating a three-way pattern. Andar Indra Sastra states that each of these systems has its own architectural style of the traditional family house which at the same time is a symbol of the identity that distinguishes the three systems from each other (Sastra, 2015: 157-157). The differences between the traditional houses of each system or community can be seen in the photographs below.
Photo 2

Architecture of the traditional Koto Piliang house (Photo: Documentation Andar 2014)
Photo 3

Architecture of the traditional Bodi Caniago house (Photo: Documentation Andar 2014)

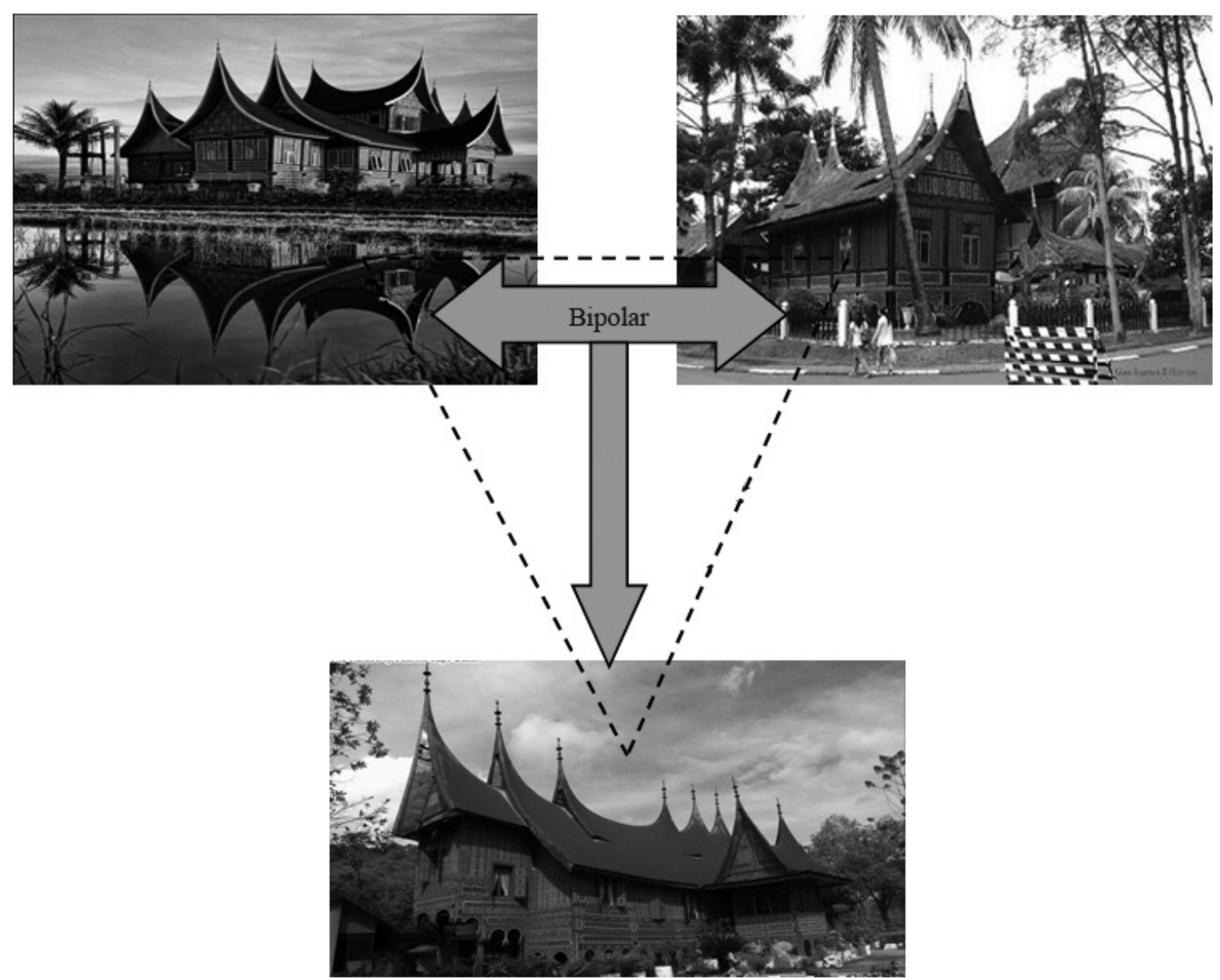

Photo 4

Architecture of the traditional Rajo Babandiang house

(Photo: Documentation Andar 2014) 
The architectural style of the traditional Koto Piliang house is characterized by the type of house known as rumah baanjuang in which both sides are raised from the ground. This symbolizes the different level in status and rank of the traditional leaders (datuak), of which the highest leader is known as the pangulu pucuak. The traditional home of Dt. Parpatiah Nan Sabatang in kelarasan Bodi Caniogo is called the surambi papek; both sides of the house are on ground level, symbolizing that the status of the leader is on an equal level to the rest of the community. The Rajo Babandiang, or Lareh Nan Panjang tradition, is a synthesis of the dialectical process between Parpatiah and Katumangguangan. The architectural style of the Rajo Babandiang house is the same as the traditional Koto Piliang house, using a traditional system which refers to that of kelarasan BodiCaniago.

The differences in the architecture of the three traditional houses shown above reflects the principle of dialectics which originated from the Parpatiah tradition with Lareh Bodi Caniago and Katumangguangan with Lareh Koto Piliangnya; meanwhile, Rajo Babandiang, with Lareh Nan Buntaor Nan Panjang, appeared as a synthesis or a counterbalance. This balance created harmony and this sense of harmony can be compared with batalun (the achievement of an aesthetical quality) in the performance of talempong renjeang which is formed by the three-way pattern created by the Jantan, Paningkah and Pangawinan. The threeway pattern created in talempong renjeang and the three-way pattern in the Minangkabau cultural system - Prapatiah, Katumangguangan, and Rajo Babandiang - both reflect a horizontal equality. This equality reflects the existence of balance in a different position, a balance which ultimately creates harmony.

Harmony symbolizes the presence of a potential for conflict which conceives dynamics as the result of a dichotomous and bipolar dualism in the community. Taufik Abdullah states that conflict exists because there is a difference in the values which form the behaviour and knowledge of the community. The meaning of conflict is viewed from the dual nature of the position of tradition and also the Islamic religion. In Minangkabau, the concept of conflict is not only recognized but is also developed in the social system itself. Conflict is viewed dialectically, as an intrinsic element for creating balance in the community (Abdullah, 1987: 107). This means that conflict holds a significant position in the development of cultural dynamics. Conflict not only causes disunity but can also act as a source of dynamics in the community. According to the opinion of Zayardam Zubir, conflict holds an important position in developing cultural dynamics. It not only leads in the direction of disunity but on the contrary, it is also a source for the dynamics of the Minangkabau community (Zubir, 2010: 33). The meaning of conflict is reflected in the traditional expression: basilang kayu dalam tungku, di sinan api makonyo hiduik, which essentially means that disputes or differences are recognized as something that should create conflict in a community. Conflict is an integral part of a community that is needed to create balance. This balance is manifested in the form of a three-way pattern, both in the performance of talempong and also in the general concept of the Minangkabau culture.

Conflict has become a part of the daily lives of the Minangkabau community. At the present time, the conflict that is developing is not of a physical or violent nature but is predominantly in the form of conflict of ideas or opinions, which are manifested through debate. Culturally, debate is an element that must be present in speeches at forums known as pasembahan adat (traditional tributes). This is a kind of forum, or medium, in which dialogue is used to debate something before a decision is made. The atmosphere of the debate in such a forum is described by the traditional expression lah lapua balapua lago ayam, lah langkang balangkang lago paruah, which means to argue or voice one's opinion, and in this expression is compared to a cock fight. This means that the representatives of all the different sides have voiced their opinions or arguments. Differences in opinion, supported by strong arguments, form the basis for leaders to make decisions.

The decision-making process in a traditional forum, which involves debating and voicing different opinions, can be analogized to the sounds and rhythms of the talempong. After all the different opinions have been expressed, the head of the meeting then forms a conclusion. 
This conclusion can also be compared to the function of the talempong Pangawinan. The concept of forming a decision through a process of debate is reflected in the interruption of the pasambahan adat, as described by Dt. Sampono in Andar Indra Sastra (2015): .... Jikok dipandang lah rancak rupo, bilo didangga lah baiak bunyi, lamak gandang mah lah batingkah, kok lamak talempong lah batalun, which means "if we see it, it looks smart, if we hear it, it sounds good, the drum sounds good when it is playing, the talempong sounds good when it achieves batalun (Sastra, 2015: 159). In the process of pasambahan, an appearance of beauty, the pleasant sound of the drum being played, and the talempong creating batalun all have a strong foundation in the culture of the Minangkabau community. According to Dt. Sampono in Andar Indra Sastra (2015), the system of decision-making in the pasambahan adat is in the sound of talempong kato (words), which forms the basis for the leader to make a decision (Sastra, 2015: 159). From this, it can be said that the talempong is not only understood as a kind of music but is also a source of inspiration for making decisions in a traditional forum. The differences of opinion in the traditional forum for decision making can be compared to the musical concept of the talempong renjeang in which there is a process of interaction which leads to an agreement to achieve a certain goal - of batalun or harmony.

Similarly, in a broader context, talempong is a cultural product, an inseparable part of the concept tali tigo sapilin dan tunggku nan tigo sajarangan - the three-way pattern. This concept may appear in various forms; in the form of a social group and in the form of the Minangkabau system of reasoning which is: (1) raso jo pareso (feel and check); (2) ukua jo jangko (measure with figures), and; (3) alua dengan patuik (flow appropriately); in the form of a traditional house, and so on. In the form of a social group, it is known in the concept tali tigo sapilin - tungku nan tigo sajarangan or urang tigo jinih (three types of people), which are: (1) niniak mamak (traditional groups); (2) alimulama (religious groups), and (3) cadiak sarato pandai (educated or intellectual groups). All three make up a unit which acts in its own field existing in a horizontal position - and maintaining social balance; the end result of this is harmony.
This harmony can be equated to batalun in the performance of talempong renjeang.

Hajizar in Andar Indra Sastra (2015) states that talempong renjeang as a musical culture is a representation of a social concept. It would not exist in the midst of the community if it was not synchronized with the social concept of the community (Sastra: 215: 160). This means that talempong renjeang is part of the social system of the Luhak Nan Tigo community in Minangkabau and at the same time represents the cultural expression of its community. T.O. Ihromi emphasizes that as a product of human behavior, music has certain structures that can reflect part of the system of ideas and actions of its community, and that culture is a reflection or material representation of the structure of human thoughts and ideas on which it is based (Ihromi, 2009: 66). As a cultural product, talempong renjeang is a reflection of the cultural concept of the community of Luhak Nan Tigo in Minangkabau - the three-way pattern in the concept of tali tigo sapilin and tungku nan tigo sajarangan.This three-way pattern and the cultural concept of the Minangkabau community ultimately form a structure which is distinguished according to its rights and responsibilities. These rights and responsibilities correspond to the musical concept and musical structure of talempong renjeang Jantan, Paningkah dan Pangawinan. The structure ...where? which one? illustrates the existence of stratification, the stratification makes the system function, and the system reflects the existence of an institution. George Ritzer-Douglas J. Goodman state that there is no community which is not stratified or is completely without class. Stratification is a functional necessity. All communities need systems and this need causes the existence of a stratification system. A stratification system is a structure and as such, it indicates that the stratification does not refer to the individuals in the stratification system but rather to the system of position - status (Ritzer - Goodman, 2008: 118). From the cultural perspective, Robert K. Merton states that a social structure is a set of organized social relationships in which members of the community or group are involved in various ways (Merton, 1986: 216). Both talempong and the concept of Minangkabau culture form a three-way pattern as a reflection of structure in different forms. 


\section{CONCLUSION}

The relationship between musical structure or musical sound - of talempong renjeang - as a cultural product and the cultural concept of the community to which the music belongs is closely interconnected. This connection is described by Alan P. Merriam, who states that a musical sound as the result of human behaviour has a certain structure. It also has a system which cannot stand alone - separate from the cultural concept of its community (Merriam, 1964: 32). This inseparability is proven by the synchronization of the structure of the three-way pattern in talempong as a cultural product and the structure of the three-way pattern in the cultural concept of the community which created it - which can be viewed as an expression of the people of Luhak Nan Tigo Minangkabau. From a sociological perspective, Fabio Dasilva (1983) in M. Jazuli states that the existence of music in a community is in fact an indication of the social and cultural phenomena or conditions in the community (Jazuli, 2014: 287). The social and cultural conditions of the Luhak Nan Tigo community are reflected in the three-way pattern as a cultural system. Talempong renjeang as a form of art - with a three-way pattern - is a medium for expressing the social life of the community.

As a cultural product, talempong renjeang is synchronized with the cultural concept of the community which created it. This synchronization can be seen in the presence of the same principle for creating a three-way pattern, both in talempong as a cultural product and also in the three-way pattern in the social system of the Luhak Nan Tigo Minangkabau community. Aesthetically, the three-way pattern in the performance of talempong renjeang produces a talempong melody that is felt to achieve a state of batalun. Harmony is the end product of the three-way pattern which is formed from the political-legal ideological conflict between the three legendary figures in Minangkabau. The conflict in ideology between these three figures produced different systems and rules of law which in turn gave rise to the concept tali tigo sapilin-tungku tigo sajarangan - all three creating harmony.

\section{REFERENCES}

Abdullah, Taufik (1987). Islam dan Masyarakat. Jakarta: Pustaka Pirdaus.

Adam, Boestanuel Arifin (1986/1987). "Talempong MusikTradisional Minangkabau". Research Report. ASKI Padangpanjang.

Ahimsa-Putra, Heddy Sri (2001). Strukturalisme LeviStrauss Mitos dan Karya Sastra. Yogyakarta: Galang Press.

Ali, Matius (2011), Estetika Pengantar Filsafat Seni, Yogyakarta: Sanggar Luxor.

Bakker, Anton (1995). Kosmologi dan Ekologi: Filsafat Tentang Kosmos Sebagai Rumah Tangga Manusia. Yogyakarta: Kanisius.

Capra, Fritjof (2005). The Tao of Physics: Mengungkap Kesejajaran Fisika Modern dan Mistisisme Timur, translated by Aufia Ilhamal Havidz. Yogyakarta: Jalasutra.

Darsono (SoniKartika). (2007), Estetika. Bandung: Rekayasa Sain.

Dobbin, Christine (1992). Kebangkitan Islam Dalam Ekonomi Petani Yang Sedang Berubah, translated by Lillian D Tedjasudana. Jakarta: Innis.

Ihromi, T.O. (2009). Pokok-pokok Antropologi Budaya. Jakarta: Yayasan Obor Indonesia.

Kato, Tsuyoshi (2005). Adat Minangkabau dan Merantau dalam Perspektif Sejarah, translated by Gusti Asnan dan Akiko Iwata. Jakarta: Balai Pustaka.

Koentjaraninggrat (2004). Manusia dan Kebudayaan I Indonesia. $20^{\text {th }}$ Edition. Jakarta: Jambatan.

Mansoer. M.D., et al. (1970). Sejarah Minangkabau. Djakarta: Bratara.

Merton, Robert K. George Ritzer - Douglas J. Goodman (2004). Teori Sosiologi Modern, sixth edition. Translated by Alimandan. Jakarta: Kencana.

Naim, Mochtar. (1981/1982). "Minangkabau dalam Dialektika Kebudayaan Nusantara." Dalam Analisis Kebudayaan, Year II. No. 2 (1981/1982), pages 87 to 93 .

Navis, Ali Akbar (1984). Alam Terkembang Jadi Guru Adat dan Kebudayaan Minangkabau. Jakarta: Temprin.

Ritzer, George-Douglas J. Goodman, Teori Sosiologi Modern (2008). Translated by Alimandan. Jakarta: Prenada Media Group. 
Sairin, Sjafri (1995). Demokrasi dalam Kebudayaan Minangkabau. Jurnal Humaniora, 87-93.

Sedyawati, Edi (2007). Budaya Indonesia Kajian Arkeologi, Seni, dan Sejarah. Jakarta: Raja Grafindo Persada.

Sumardjo, Yakob (2010). Estetika Pradoks. STSI Bandung: Penerbit Sunan Ambu Press.

Sastra, Andar Indra (2015). “Konsep Batalun Dalam Penyajian Talempong Renjeang Anam Salabuhan Di Luhak Nan Tigo Minangkabau”. Dissertation. Postgraduate Program Institut Seni Indonesia Surakarta.

(2015). The Group Concept Of Building Raso Batalun In The Performance Of
Talempong Renjeang Anam Salabuhan. Jurnal Humaniora 42-52.

(2016). "Sistem Matrilineal dan Budaya Perunggu: Estetika Pola Dua Sebagai Dasar Pembentukan Satu Sistem Musik Talempong Renjeang Anam Salabuhan". Presented at Symposium Creativity \& Art Studies Di ISI Yogyakarta 23-24 May 2016.

Pramono, Kartini (2009). Horizon Estetika, Yogyakarta: Kahfi Offset Fakultas Filsafat Universitas Gadjah Mada.

Zubir, Zaiyardam (2010). Budaya Konflik dan Jaringan Kekerasan. Yogyakarta: Insist Press. 